\title{
Soil Bulk Density and Water Infiltration as Affected by Grazing Systems
}

\author{
AHMED H. ABDEL-MAGID, GERALD E. SCHUMAN, AND RICHARD H. HART
}

\section{Abstract}

The influences of continuous, rotationally deferred, and shortduration rotation grazing systems on soil compaction and water infiltration were assessed. Bulk density and water infiltration were measured to evaluate the effects of the 3 grazing systems at moderate and heavy stocking rates. Measurements were made in the spring before grazing and at the end of the grazing season in 1983 and 1984. Bulk density was not affected by grazing systems or stocking rate; bulk density was greater in the fall than in spring of 1984 , but not in 1983 . Infiltration was significantly lower under the heavy stocking rate than under the moderate stocking rate at the end of the grazing season. The average water infiltration was significantly less in the fall than in the spring for the heavy stocking rate but showed no seasonal effect for the moderate stocking rate. Infiltration was significantly greater under continuous grazing than under rotational deferment but no different from that under short-duration grazing in 1983. However, in 1984 the relationship was reversed. The grazing systems evaluated did not affect soil bulk density and water infiltration in a consistent manner; however, the stocking rate resulted in reduced infiltration during the grazing season.

Key words: Short-duration grazing, compaction, sandy loam soil, short grass rangelands.

In recent years much attention has been focused on the claims made by the supporters of the "Savory grazing method", more recently renamed the "Holistic management system." Savory and Parsons (1980) stated that physical animal impact was not detrimental to deteriorating arid rangeland but was in fact desirable to hasten the advance of plant succession. They believed that this was achieved through hoof action, which improved water penetration by breaking up hard surface crusts and algae, lichen, and moss communities. Heitschmidt and Walker (1983) questioned the Savory grazing method and indicated that if the method was successful, it would not be because of benefits of the physical animal impacts.

Numerous studies of the effects of grazing on soil physical parameters have been accomplished during the past 2 decades. Thurow et al. (1986) found that water infiltration rates under short-duration grazing were lower than rates under moderatelystocked continuous grazing on bunch- or sodgrass but did not differ in oak mottes. Infiltration under heavy-stocked continuous grazing was slower than under short-duration grazing on sodgrass but not in oak mottes. Wood and Blackburn (1981) found no differences in infiltration rates between a high-intensity lowfrequency (HILF) system and continuous grazing under moderate or heavy stocking. Infiltration rate under deferred-rotation grazing was higher than that in recently grazed HILF pastures but not in rested HILF pastures in midgrass interspaces, shortgrass interspaces or under a shrub canopy. They reported bulk density as one variable that influenced infiltration, but aggregate stability and organic matter content had greater influences.

Rauzi and Hanson (1966) found that water intake rates on several watersheds decreased almost linearly as intensity of grazing

\footnotetext{
The authors are research associate, Dept. of Range Science, Colorado State University, Fort Collins 80523; soil scientist and range scientist, respectively, USDA, Agricultural Research Service, High Plains Grasslands Research Station, 8408 Hildreth Road, Cheyenne, Wyo. 82009.

The authors wish to thank Paul Brown of the USDA/ARS for his field assistance.

Manuscript accepted 7 February 1987.
}

increased. Rauzi and Smith (1973) concluded that, on Ascalon sandy loam and Nunn loam, infiltration rate was higher on lightly and moderately grazed pastures than on heavily grazed pastures. Bryant et al. (1972) reported that soil compaction increased linearly with increased grazing intensity. However, Van Haveren (1983) found that degree of soil compaction, as measured by bulk density, depended on the texture of the soil as well as on the soil water content at the time of grazing and on the level of organic matter in the surface soil. Linnartz et al. (1966) found that 10 years of grazing during spring and summer resulted in sufficient soil compaction to restrict water movement into and through the soil profile in central Louisiana, especially during intense rain storms.

Thompson (1968) found that grazing affected infiltration less than did seasonal changes in surface soil characteristics. Achouri and Gifford (1984) also reported significant differences in infiltration among seasons of the year.

The objective of this study was to evaluate differences among 3 grazing systems (continuous or season-long, rotationally deferred, and short-duration rotation) and 2 stocking rates on soil bulk density and water infiltration rate of mixed-grass prairie in southeastern Wyoming.

\section{Materials and Methods}

The pastures were established at the High Plains Grasslands Research Station, Cheyenne, Wyo., to study 3 grazing systems: continuous $(C)$, rotational deferment $(R)$, and short-duration rotation (S) with 2 stocking rates: heavy (H), 2.25 ha/steer and moderate (M), $3.0 \mathrm{ha} / \mathrm{steer}$. The continuous grazing system was also

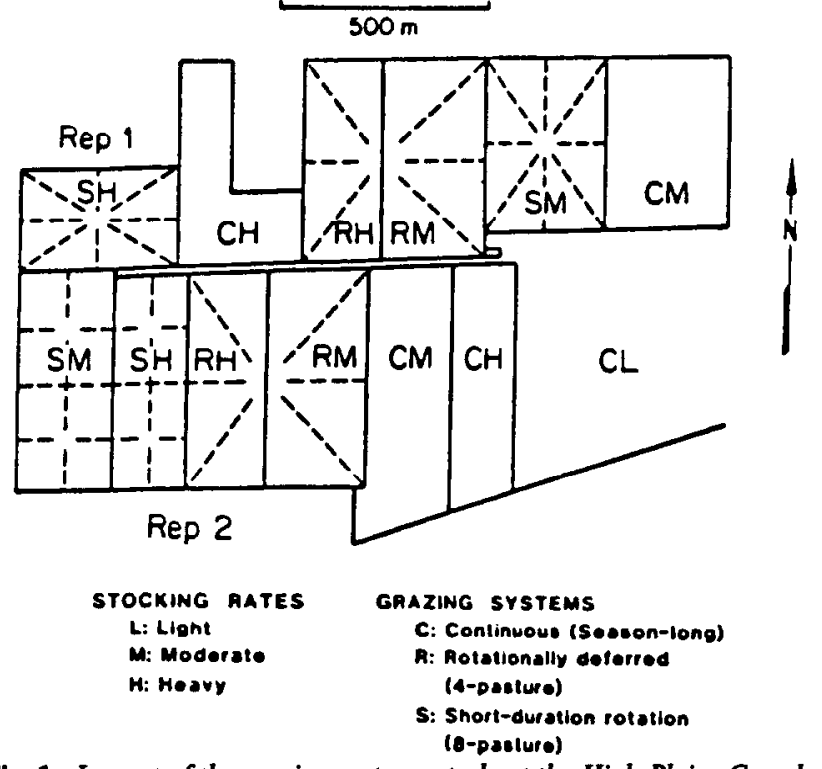

Fig. 1. Layout of the grazing systems study at the High Plains Grasslands Research Station, Cheyenne, Wyo.

stocked at a light (L) rate, $5.25 \mathrm{ha} / \mathrm{steer}$. All pastures were grazed from June through October. The 3 grazing systems (C, R, and $S)$ were as described by Launchbaugh et al. (1978), Koerth et al. (1983) and Savory (1978). In the short-duration rotation system the pasture was divided into 8 subunits (paddocks). The layout of the pastures with 2 replications (except CL) is shown in Figure 1. 
From 1976 to 1978 , the pastures were grazed very lightly by cattle; from 1979 to 1982 and for a number of years prior to 1976 they were not grazed by livestock.

One permanent transect of $25 \mathrm{~m}$ was established in each pasture stocked at $\mathbf{M}$ and $H$. All transects were established on an Ascalon sandy loam soil (fine, loamy, mixed, mesic Aridic Arguistoll). Selected physiochemical characteristics of the soil are shown in Table 1 .

Table 1. Selected physiochemical characteristics of the Ascalon soil from the study area, High Plains Grasslands Res. Sta. Cheyenne, Wyoming. (Stevenson et al. 1984).

\begin{tabular}{lcccclc}
\hline \hline & & \multicolumn{3}{c}{ Particle size } & \multirow{2}{*}{$\begin{array}{c}\text { Organic } \\
\text { matter }\end{array}$} \\
\cline { 3 - 6 } Horizon & Depth & Sand & Silt & Clay & Texture & $\%$ \\
A & cm & $\%$ & $\%$ & $\%$ & & 2.3 \\
Bt1 & $0-13$ & 67 & 18 & 15 & Sandy loam & 0.9 \\
Bt2 & $13-28$ & 64 & 14 & 22 & Sandy clay loam & 0.7 \\
Btk & $28-36$ & 70 & 13 & 17 & Sandy loam & 0.6 \\
Bk & $36-48$ & 65 & 14 & 21 & Sandy loam & 0.2 \\
C & $48-102$ & 73 & 10 & 17 & Sandy loam & 0.1 \\
\hline
\end{tabular}

A press core device (Lutz 1947) was used to take undisturbed soil cores $5 \mathrm{~cm}$ in diameter from the surface $5 \mathrm{~cm}$ of soil. Twenty samples were taken at $1.2-\mathrm{m}$ intervals along each transect in each pasture. Sampling was done at the beginning of the growing season before cattle had been put on the pastures (spring) and at the end of the grazing period about 4 months later (fall) during 1983 and 1984. The samples were placed in metal soil cans, dried at $105^{\circ} \mathrm{C}$, weighed, and bulk density was calculated.

Water infiltration measurements were taken near each end of the permanent transect in each pasture in the spring and fall of 1983 and 1984. This resulted in 2 observations per replication, hence 4 measurements per grazing treatment. The variation in infiltration rate within a pasture was only $58 \%$ of that observed between replicate pastures; therefore increasing the number of observations within a pasture would not have significantly increased the precision of the measurement. Bulk density and infiltration sample sites were selected to insure that similar kinds and amounts of vegetation and similar proportions of vegetation and bare soil were present.

Water infiltration was measured with a double-ring infiltrometer (Haise et al. 1956) with a $15-\mathrm{cm}$ head maintained during the measurement. The diameter of the inner and outside rings were $\mathbf{3 0}$ and $60 \mathrm{~cm}$, respectively. Readings of water level were taken at 0,5 , $10,15,20,30,45,60,90$, and 120 minutes. Actual cumulative intake of water was recorded for each time interval throughout the 2-hour period. Infiltration data for the last 30 minutes of the 2 -hour period were used to calculate equilibrium infiltration rate.

Water infiltration data were used to assess the relative effects of levels of animal compaction on the soil, and not the effect of the grazing system on the total hydrology of the ecosystem (Branson et al. 1981). If infiltration rate in relation to surface runoff and erosion are primary objectives, then a rainfall or sprinkler infiltrometer will enable improved hydrologic analysis since it more closely simulates the natural rainfall-infiltration relationship and integrates the effect of raindrop impact energy into the system (Gifford and Hawkins 1978).

Bulk density, equilibrium infiltration rate, and cumulative infiltration data were analyzed as a $2 \times 3$ factorial in a randomized complete block design with 2 replications. Duncan's new multiple range test $(P=0.10)$ was used to separate means associated with stocking rate, grazing system, season of sampling, and year.

\section{Results and Discussion}

Bulk density was not significantly different $(P=0.10)$ among grazing systems, stocking rates, or seasons (fall and spring) in 1983. Bulk density was significantly greater in the fall $1984\left(1.28 \mathrm{~g} / \mathrm{cm}^{3}\right)$ than in the spring $1984\left(1.19 \mathrm{~g} / \mathrm{cm}^{3}\right)$, but there were no differences among grazing systems or stocking rates (Table 2). Bulk density of the soil did not vary much during the 2-year period (1.19 to 1.28 $\left.\mathrm{g} / \mathrm{cm}^{3}\right)$.

Table 2. Soil bulk density $\left(\mathrm{g} / \mathrm{cm}^{3}\right)$ as influenced by season and year, High Plains Grasslands Research Station, Cheyenne, Wyoming.

\begin{tabular}{lll}
\hline \hline Year & Spring & Fall \\
\hline 1983 & $1.25 \mathrm{a}^{1}$ & $1.25 \mathrm{a}$ \\
1984 & $1.19 \mathrm{~b}$ & $1.28 \mathrm{a}$ \\
\hline
\end{tabular}

'Means followed by the same letter within year are not significantly different $(P \leq 0.10)$.

Increased bulk density can be attributed to the static or standing loads of the grazing steers and the greater loads exerted per unit area of soil when they were moving during the 4-month grazing period (Lull 1959). However, under the conditions of this experiment, soil texture was not fine enough to allow for as much compaction as found by Van Haveren (1983). Laycock and Conrad (1967) also observed increases in bulk density both on grazed areas and exclosures during the grazing season, but the soils in their study area contained more clay and silt than the Ascalon soil, resulting in greater soil water during the early spring grazing period and the potential for greater compaction.

The freezing and thawing action of soil may have resulted in the decrease in the spring 1984 bulk density values after the soil was compacted by grazing in fall 1983. The difference in bulk density between the 2 spring and 2 fall seasons may be attributed to the difference in precipitation and temperature. Rainfall was greater in Sept-Oct 1984 (74 mm) than in Sept.-Oct. $1983(23 \mathrm{~mm})$, which made the soil more susceptible to compaction during Sept-Oct 1984. Rainfall was greater in March-May $1983(292 \mathrm{~mm})$ than 1984 (146), but steers were not put on the pastures until June; therefore the soil moisture was similar at the time of sampling. The average minimum temperatures of Dec. $1983\left(-15.2^{\circ} \mathrm{C}\right)$ and Jan. $1984\left(-10.1^{\circ} \mathrm{C}\right)$ were lower than those of Dec. $1982(-7.6)$ and Jan. $1983(-6.1)$. the difference in spring precipitation and minimum temperatures might have caused the variation in soil bulk density between the 2 spring seasons (Baver et al. 1972).

Water infiltration exhibited a year-by-grazing system and a season-by-stocking rate interaction for both equilibrium infiltration and cumulative infiltration and a year-by-stocking rate interaction for equilibrium infiltration data. In evaluating the year-bygrazing systems interactions for infiltration, the equilibrium and cumulative water intake data generally exhibited similar trends (Table 3). The continuous grazing treatment had an average equilibrium infiltration rate of $9.69 \mathrm{~cm} / \mathrm{hr}$ in 1983 which was significantly greater than that observed for the rotational deferment treatment but no different than for the short-duration treatment.

Table 3. Graxing system $\times$ year effects on equilibrium and cumulative water inflitration rates, High Plains Grasslands Research Station, Cheyenne, Wyoming.

\begin{tabular}{|c|c|c|c|c|}
\hline Variable & Year & & Grazing System & \\
\hline \multirow[t]{2}{*}{$\begin{array}{l}\text { Equilibrium water } \\
\text { infiltration }(\mathrm{cm} / \mathrm{hr})\end{array}$} & & Continuous & Rotational & $\begin{array}{l}\text { Short- } \\
\text { duration }\end{array}$ \\
\hline & $\begin{array}{l}1983 \\
1984\end{array}$ & $\begin{array}{l}9.69 \mathrm{a}^{\prime} \\
7.18 \mathrm{~b}\end{array}$ & $\begin{array}{l}8.13 \mathrm{~b} \\
9.02 \mathrm{ab}\end{array}$ & $\begin{array}{c}8.99 \mathrm{ab} \\
10.40 \mathrm{a}\end{array}$ \\
\hline \multirow{2}{*}{$\begin{array}{l}\text { Cumulative water } \\
\text { infiltration }(\mathrm{cm} / 2 \mathrm{hrs})\end{array}$} & & & & \\
\hline & $\begin{array}{l}1983 \\
1984\end{array}$ & $\begin{array}{l}23.05 \mathrm{a} \\
16.82 \mathrm{~b}\end{array}$ & $\begin{array}{c}20.90 \mathrm{a} \\
17.58 \mathrm{~b}\end{array}$ & $\begin{array}{l}22.87 \mathrm{a} \\
23.27 \mathrm{a}\end{array}$ \\
\hline
\end{tabular}

'Means within a year within a variable followed by the same letter a re not significantly different $(P \leq 0.10)$. 
In 1984 the short-duration grazing treatment exhibited the highest equilibrium water infiltration rate and the continuous grazing treatment the lowest.

The season-by-stocking rate interactions exhibited the same trends for equilibrium and cumulative water infiltration (Table 4).

Table 4. Stocking rate - season effects on equilibrium and cumulative water infiltration rates, High Plains Grasslands Research Station, Cheyenne, Wyoming, 1983-1984.

\begin{tabular}{lccc}
\hline \hline & & \multicolumn{2}{c}{ Stocking rate } \\
\cline { 4 - 4 } Variable & Season & Moderate & Heavy \\
\hline $\begin{array}{l}\text { Equilibrium water infiltration } \\
\text { (cm/hr) }\end{array}$ & Spring & $8.49 \mathrm{a}^{1}$ & $9.09 \mathrm{a}$ \\
& Fall & $10.15 \mathrm{a}$ & $7.87 \mathrm{~b}$ \\
& & & \\
Cumulative water infiltration & Spring & $21.15 \mathrm{a}$ & $21.43 \mathrm{a}$ \\
$\quad(\mathrm{cm} / 2 \mathrm{hrs})$ & Fall & $22.24 \mathrm{a}$ & $18.17 \mathrm{~b}$ \\
\hline
\end{tabular}

'Means within a season or stocking rate within a variable followed by the same letter are not significantly different.

The average water infiltration rate (equilibrium and cumulative) was significantly less in the fall than in the spring for the heavy stocking rate, but showed no seasonal effect for the moderate stocking rate. The moderate stocking rate had significantly greater infiltration than the heavy stocking rate at the end of the grazing season. No significant differences in infiltration between stocking rates existed in the spring, indicating that the freeze-thaw activity each winter alleviated any detrimental soil compaction that reduced infiltration. In 1983, the equilibrium infiltration was less under heavy stocking than under the moderate stocking rate (Table 5). However, in 1984 no differences in infiltration were observed between the 2 stocking rates. This year-to-year variation is not fully understood, and may be better evaluated in a longer-term study and on a soil and vegetation type that is more susceptible to compaction by hoof action.

Table 5. Stocking rate and year effects on water infiltration rate $(\mathrm{cm} / \mathrm{hr})$, High Plains Grasslands Research Station, Cheyenne, Wyoming.

\begin{tabular}{lcl}
\hline \hline & \multicolumn{2}{c}{ Stocking rate } \\
\cline { 2 - 3 } Season & Moderate & Heavy \\
\hline 1983 & $9.79 \mathrm{a}^{\mathrm{t}}$ & $8.08 \mathrm{~b}$ \\
1984 & $8.85 \mathrm{a}$ & $8.88 \mathrm{a}$ \\
\hline
\end{tabular}

'Means followed by the same letter within a year are not significantly different $(P \leq 0.10)$

Both the equilibrium and cumulative infiltration were evaluated because of concerns that an equilbrium measurement may not reflect small changes due to differences in surface compaction and soil moisture content at the time of sampling. However, soil moisture content of the top $5 \mathrm{~cm}$ of soil at the time of sampling appeared to have no influence on bulk density or cumulative water infiltration. Regression analysis of soil water content versus bulk density and cumulative water infiltration resulted in coefficients of determination $\left(r^{2}\right)$ of 0.02 and 0.06 , respectively.

\section{Conclusion}

The grazing systems did not consistently influence bulk density and water infiltration. Trends in water infiltration rate did not follow those of bulk density. This indicated that soil bulk density may not be the main factor that controlled water infiltration rate (Orr 1975). However, the study indicated that the short-duration rotation grazing system had no clear advantage for improving water infiltration by destruction of surface crusting. The heavy stocking rate consistently reduced infiltration during the grazing season, but this appeared to be alleviated during the winter by freeze-thaw activities. Long-term evaluation of the effects of grazing systems on soil physical characteristics may help to overcome seasonal, yearly, and inherent soil variability.

\section{Literature Cited}

Achouri, M., and G.F. Gifford. 1984. Spatial and seasonal variability and field measured infiltration rates on a rangeland site in Utah. J. Range Manage. 37:451-455.

Baver, L.D., W.H. Gardner, and W.R. Gardner. 1972. Soil physics. Fourth Edition. John Wiley and Sons, Inc. New York.

Branson, F.A., G.F. Gifford, K.G. Renard, and R.F. Hadley. 1981. Rangeland hydrology, 2nd Edition. Kendall/Hunt Pub. Co. Dubuque, Iowa.

Bryant, H.T., R.E. Blaser, and T.R. Peterson. 1972. Effect of trampling by cattle on bluegrass yield and soil compaction of a meadowville loam. Agron. J. 64:331-334.

Gifford, G.F., and R.H. Hawkins. 1978. Hydrologic impact of grazing on infiltration: A critical review. Water Resources Res. 14:305-313.

Haise, H.F., W.W. Donnan, J.T. Phelan, L.F. Lawhon, and D.G. Shockley. 1956. The use of cylinder infiltrometers to determine the intake characteristics of irrigated soils. ARS 41-47. Agr. Res. Ser. and Soil Cons. Serv, USDA. U.S. Gov. Printing Office, Washington, D.C.

Hart, R.H., P.S. Test, M.J. Samuel, and M.A. Smith. 1987. Cattle and vegetation response to grazing systems and stocking rates on the Wyoming High Plains. J. Range Manage. (In press).

Heitschmidt, R., and J. Walker. 1983. Short duration grazing and the Savory Grazing Method in perspective. Rangelands 5:147-150.

Koerth, B.H., W.M. Webb, F.C. Bryant, and F.S. Guthery. 1983. Cattle trampling of simulated ground nests under short duration and continuous grazing. J. Range Manage. 36:385-386.

Launchbaugh, J.L., C.E. Owensby, F.L. Schwartz, and L.R. Corah. 1978. Grazing management to meet nutritional and functional needs of livestock. p. 541-546. In: Proc. Ist Internat. Rangelands Congress.

Laycock, W.A., and P.W. Conrad. 1967. Effect of grazing on soil compaction as measured by bulk density on a high elevation cattle range. J. Range Manage. 20:136-140.

Linnartz, N.E., Chung-Yun Hse, and V.I.. Dunval. 1966. Grazing impairs physical properties of a forest soil in Central Louisiana. J. Forestry 64:239-243.

Lull, H.W.1959. Soil compaction on forest and rangelands. USDA. Forest Serv. Misc. Pub. No. 768.

Lutz, J.R. 1947. Apparatus for collecting undisturbed soil samples. Soil Sci. 64:399-401.

Orr, H.K. 1975. Recovery from soil compaction on bluegrass range in the Black Hills. Trans. Amer. Soc. Agr. Engr. 18:1076-1081.

Rauzi, F., and C.L. Hanson. 1966. Water intake and runoff as affected by intensity of grazing. J. Range Manage. 19:351-356.

Rauxi, F., and F.M. Smith. 1973. Infiltration rates: Three soils with three grazing levels in northeastern Colorado. J. Range Manage. 26:126-129.

Savory, A. 1978. A holistic approach to ranch management using short duration grazing. p. 555-557. In. Proc. Ist Internat. Rangelands Congr.

Savory, A., and S.D. Parsons. 1980. The Savory grazing method. Rangelands 2:234-237.

Stevenson, A., R.E. Baumgartner, and G.E. Schuman. 1984. High Plains Grasslands Research Station detailed soil survey. Wyo. Agr. Exp. Sta. Spec. Pub. February 1984. Laramie.

Thompson, J.R. 1968. Effect of grazing on infiltration in a western watershed. J. Soil and Water Conserv. 23:63-65.

Thurow, T.L., W.H. Blackburn, and C.A. Taylor, Jr. 1986. Hydrologic characteristics of vegetation types as affected by livestock grazing systems, Edwards Plateau, Texas. J. Range Manage. 39:505-509.

Van Haveren, B.P. 1983. Soil bulk density as influenced by grazing intensity and soil type on a shortgrass prairie site. J. Range Manage. 36:586-588.

Wood, M.K., and W.H. Blackburn. 1981. Grazing systems: Their influence on infiltration rates in the rolling plains of Texas. J. Range Manage. 34:331-355. 